\title{
Study of the combined radial post-feeding dispersion of the blowflies Chrysomya megacephala (Fabricius) and C. albiceps (Wiedemann) (Diptera, Calliphoridae)
}

\author{
Leonardo Gomes ${ }^{1} \&$ Claudio José Von Zuben ${ }^{1,2}$
} 'Departamento de Zoologia, Universidade Estadual Paulista, Av. 24A, 1515, 13506-900 Rio Claro-SP, Brasil. leugomes@yahoo.com.br
${ }^{2}$ Bolsista do CNPq.

\begin{abstract}
Study of the combined radial post-feeding dispersion of the blowflies Chrysomya megacephala (Fabricius) and C. albiceps (Wiedemann) (Diptera, Calliphoridae). Blowflies use discrete and ephemeral substrates to feed their larvae. After they run out of food, the larvae begin to disperse in order to find adequate places for pupation or additional food sources, a process named post-feeding larval dispersion. Some important aspects of this process were studied in a circular arena allowing the combined radial post-feeding dispersion from the center of the arena of C. albiceps and C. megacephala larvae. To determine the location of each pupa, the arena was divided in 72 identical sections starting from the center. The distance from the center, the depth and weight of each pupa were evaluated. Statistical tests were done to verify the relation between weight, depth and distance for pupation. From the total an average of 976 larvae released (488 for each species) were collected considering both experiments 456 C. megacephala pupae and 488 of C. albiceps. This demonstrates that $C$. albiceps probably preyed on 32 C. megacephala larvae during post-feeding dispersion. The study of this dispersion process can be used to estimate the postmortem interval (PMI) of human cadavers in legal medicine.
\end{abstract}

KEYWORDS. Calliphoridae; C. albiceps; C. megacephala; dispersion; forensic entomology.

\begin{abstract}
RESUMO. Estudo da dispersão radial combinada de Chrysomya megacephala (Fabricius) e C. albiceps (Wiedemann) (Diptera, Calliphoridae). As moscas- varejeiras utilizam-se de substratos discretos e efêmeros para alimentar suas larvas. Após deixarem o substrato alimentar, as larvas começam a dispersar em busca de locais adequados para pupação e fontes adicionais de alimento, um processo denominado dispersão larval pós-alimentar. Alguns aspectos importantes desse processo foram estudados em uma arena permitindo a dispersão radial combinada de larvas de C. megacephala e $C$. albiceps. Para determinar a localização de cada pupa, a arena foi dividida em 72 setores iguais começando do centro. A distância a partir do centro, a profundidade e o peso de cada pupa foram determinados. Testes estatísticos foram feitos para verificar a relação entre peso, profundidade e distância para pupação. De um total em média de 976 larvas soltas (488 de cada espécie) foram coletadas considerando ambos os experimentos 456 larvas de C. megacephala e 488 larvas de C. albiceps. Isso demonstrou que as larvas de C. albiceps provavelmente predaram 32 larvas de C. megacephala. O estudo desse processo de dispersão pode auxiliar na estimativa do intervalo pós- morte (IPM) em estudos de medicina legal.
\end{abstract}

PALAVRAS-CHAVE. Calliphoridae; C. albiceps; C. megacephala; dispersão; entomologia forense.

Flies of the genus Chrysomya have great medico-sanitary importance as they carry enteropathogenics such as viruses, bacteria and helmints (Furlanetto et al. 1984; Lima \& Luz 1991) and they may cause myiases to animals and men (Zumpt 1965; Guimarães et al. 1983). They are also of fundamental importance in forensic entomology studies, as they can be indicators of the decomposition time of human cadavers (Greenberg 1991; Von Zuben et al. 1996).

Chrysomya flies have drawn attention for being an exotic species and for their impact on the native community of necrophagous dipterans (Wells \& Greenberg 1992). The impact caused by the introduction of exotic species is interesting both to ecologists and evolutionists who study the process of these invasions, which include competition, predation and dispersion as well as stability and extinction of local populations (Hengeveld 1989). The understanding of the phenomena involved in this invasion process depends on the study of certain population parameters and the space-time environmental structure in which these phenomena occur (Wiens 1976; Hengeveld 1989). Besides these, there are other phenomena of small spatial scale like such as the dispersion of immature stages of the invading organisms. In this context and in the specific case of the necrophagous flies, the postfeeding larval dispersion in search of a pupation site may be mentioned.

The substrates in which blowflies develop are called discrete and ephemeral because they are units separated in space and last a short period of time due to the rapid and successive changes they undergo (Atkinson \& Shorrocks 1981). Normally these substrates are saturated with insects of one or more species (Beaver 1977), involving an intense competition for resources (Hanski 1987).

The larval stage is the main period when blowflies face limits on food resources. The competition for these resources is generally of the exploitative type (Levot et al. 1979; Goodbrod \& Goff 1990; Reis et al. 1994), where each larva attempts to 
Table I. Depth, distance and weight (average and standard deviation) of Chrysomya megacephala and Chrysomya albiceps pupae in four quadrants of the arena $2 \mathrm{~m}$ diameter. The first quadrant corresponds to sectors from 1 to $90^{\circ}$, the second quadrant from 91 to $180^{\circ}$, the third from 181 to $270^{\circ}$, and the forth from 271 to $360^{\circ}$.

\begin{tabular}{ccccc}
\hline Quadrant & 1 & 2 & 3 & 4 \\
\hline Average depth \pm \pm SD (cm) & $4.13 \pm \pm 1.08$ & $4.46 \pm \pm 2.01$ & $4.69 \pm \pm 1.34$ & $4.12 \pm \pm 2.09$ \\
Average distance \pm \pm SD (cm) & $31.12 \pm \pm 2.16$ & $24.25 \pm \pm 1.78$ & $29.99 \pm \pm 2.56$ & $34.25 \pm \pm 1.73$ \\
Average weight \pm \pm SD (mg) & $39.16 \pm \pm 4.66$ & $38.90 \pm \pm 5.96$ & $43.14 \pm \pm 5.12$ & $37.32 \pm \pm 6.98$ \\
\hline
\end{tabular}

feed as much as possible before the complete exhaustion of resources (Ullyett 1950; Backer 1961; 1969; De Jong 1976; Levot et al. 1979; Lominicki 1988).

Following this competition, the larvae begin to search for a pupation site in the habitat or for another source of food if they do not have enough weight for pupation. This process is called post-feeding larval dispersion (Greenberg 1990).

Some studies on caliphorid larval dispersion have already been done as is the case of Greenberg (1990), Kocarek (2001) and others involving mathematical models as the ones on postfeeding larval dispersion restricted to one direction regarding diffusion equations (Bassanezi et al. 1997), on statistical analyses of spatial distribution (Godoy et al. 1995; 1996; Von Zuben et al. 1996; Gomes et al. 2002; Gomes \& Von Zuben 2003), and on non-local interactions (Boldrini et al. 1997). All of these are a basis for future experimental studies simulating the natural environment, as proposed in this study.

The objective of this study is to investigate the interspecific radial post-feeding larval dispersion considering C. megacephala and C. albiceps, because this dispersion reflects more accurately the larval dispersion process that occurs in their natural environment compared to former studies which considered only one species at a time.

\section{MATERIAL AND METHODS}

C. megacephala and C. albiceps specimens were collected around the Biosciences Institute of Unesp in Rio Claro, São Paulo, Brazil. Decaying organic matter was used as bait and the specimens collected were maintained in screen cages in a controlled temperature room at $25 \pm 1^{\circ} \mathrm{C}, 60 \%$ relative humidity and 12-hour photoperiod.

Larval densities were formed with C. megacephala and $C$. albiceps individuals in macerated bovine meat. After the larvae developed, the meat was placed in the center of a circular arena (illuminated, to avoid tendencies) for them to move out of it. Arenas with $2 \mathrm{~m}$ in diameter, covered with $5 \mathrm{~cm}$ of wood shavings were used. An average of 976 larvae were used in two trials: a test (968 larvae, 484 from each species) and a replicate (984 larvae, 492 from each species).

After the larvae pupated, they were located and removed from the wood shavings. The depth of the pupation site and its distance from the center of the arena were measured with rulers and measuring tapes. The counting was done from the periphery to the center and the arena was divided in 72 sectors of 5 degrees each and four quadrants.

At the same time that pupae were collected, each pupa was weighed on an Ohaus analytical scale before the adults emerged and after individualized in plastic flasks. Pupal weight was measured in milligrams, with a precision of $0.01 \mathrm{mg}$. After they were weighted, each larva was returned to its individual flask for identification of species and sex of the adults after their emergence. The depth the larvae buried themselves was measured in centimeters. Burial depth was measured as a discrete variable, that is, it is represented by whole numbers from 0 to 5 .

Distance of burial was measured as a discrete variable, that is, it is represented by whole numbers from 1 to 5 , where 1 includes the interval from 0 to $20 \mathrm{~cm}, 2$ includes the interval from $21 \mathrm{~cm}$ to $40 \mathrm{~cm}, 3$ includes the interval from $41 \mathrm{~cm}$ to $60 \mathrm{~cm}$, 4 includes the interval from $61 \mathrm{~cm}$ to $80 \mathrm{~cm}$ and finally 5 includes the interval from $81 \mathrm{~cm}$ to $100 \mathrm{~cm}$ from the center of arena. The distance from the center of the circumference to the burial site was also measured in centimeters.

A correlation test were performed to analyze the correlation

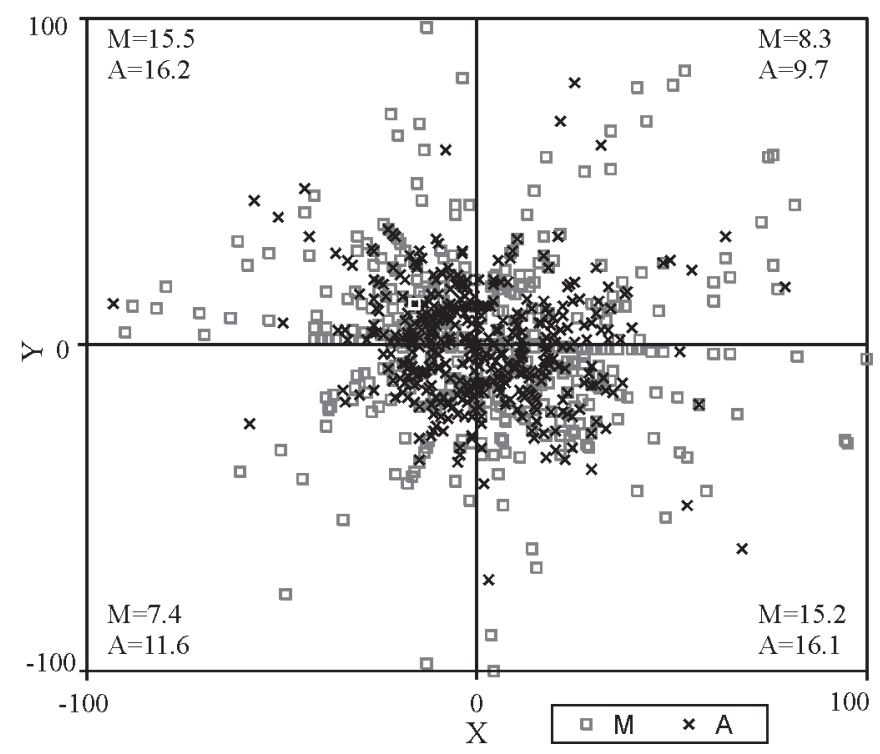

Fig. 1. Species distribution in the dispersion arena (species $\mathrm{M}=C$. megacephala and $\mathrm{A}=$ C. albiceps). 


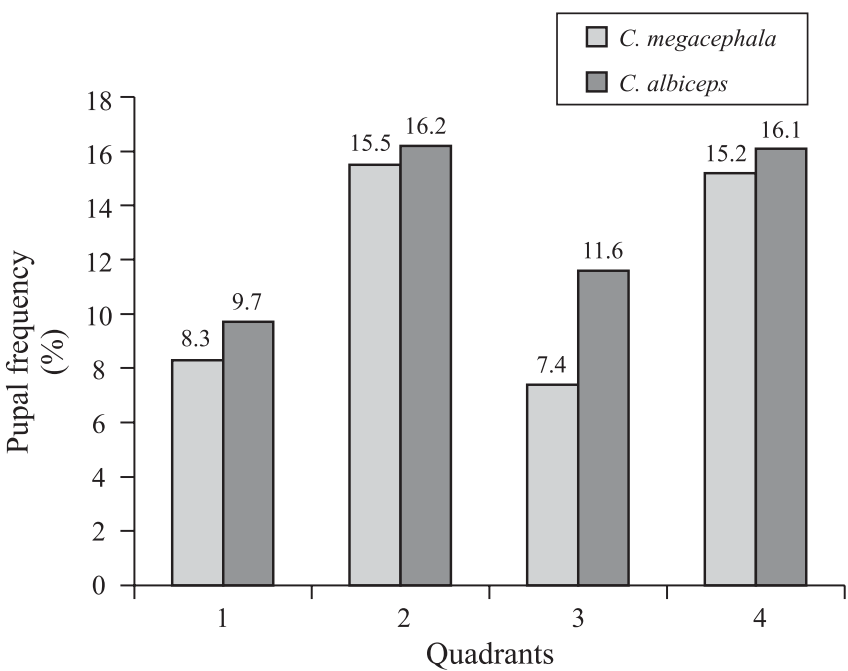

Fig. 2. Pupal frequency (\%) per quadrant $C$. albiceps and $C$. megacephala.

among variables and Anova test to check the difference among 2 experiments (Zar, 1999).

\section{RESULTS}

Combined radial post-feeding larval dispersion in Chrysomya megacephala and Chrysomya albiceps (considering both species jointly). Considering both experiments, from the total number of larvae released, 976 were collected on average: 456 C. megacephala pupae and $488 C$. albiceps. This demonstrates that $C$. albiceps probably preyed on 32 C. megacephala larvae during the process of postfeeding dispersion because there was no blowfly flying in the room after the end of collecting the pupae.

Average and standard deviation for burial depth, distance from the arena center and weight of the larvae in all four quadrants of the arena are represented on Table I. The first quadrant corresponds to sectors from 1 to $90^{\circ}$, the second quadrant from 91 to $180^{\circ}$, the third from 181 to $270^{\circ}$, and the forth from 271 to $360^{\circ}$.

Considering the distribution of both species jointly in the arena (Fig. 1), 31.7\% of the total preferred the quadrant 2 while only $18 \%$ went to quadrant 1 .

The Fig. 2 shows the presence of pupae (976) of each species in each quadrant. The presence of $C$. albiceps is greater in all quadrants, which may indicate that $C$. albiceps larvae preyed on C. megacephala larvae. Considering the presence of pupae on different depths, both species preferred to pupate deeper (Fig. 3).

The distribution and frequency of pupae in relation to their distance from the arena's center were also analyzed. Distances between 0 and $20 \mathrm{~cm}$ correspond to the first interval, the second interval from 21 to $40 \mathrm{~cm}$, up to the fifth level, which corresponds to an interval from 81 to $100 \mathrm{~cm}$ of distance. Most pupae were concentrated in levels 1 and 2 (Fig. 4).
The larval weight distribution is shown in Fig. 5.

Average pupation weight was $39.2 \mathrm{mg}$ and most larvae (700 approximately) weighed between 37 and $43 \mathrm{mg}$. Table II reinforces both previous graphs regarding sex distribution, because it demonstrates how each blowfly species was located according to gender. From 488 C. albiceps larvae, 265 females were located at an average distance of $23.44 \mathrm{~cm}$ whereas 223 males reached $20.44 \mathrm{~cm}$ in average. From 456 C. megacephala larvae, 224 females were located at an average distance of $31.93 \mathrm{~cm}$ whereas 232 males reached $31.83 \mathrm{~cm}$ on average. Regarding burial depth, C. albiceps males buried deeper than females, reaching an average depth of $4.02 \mathrm{~cm}$, while $C$. megacephala females buried deeper than males $(4.20 \mathrm{~cm})$. Despite these differences, C. megacephala larvae presented greater average results for all variables, particularly distance, which was $31.88 \mathrm{~cm}$ for $C$. megacephala and $22.02 \mathrm{~cm}$ for $C$. albiceps. C. albiceps larvae preyed on 32 C. megacephala larvae considering both experiments. There was no significant difference between the two experiments $(\operatorname{Stat} t=1.2)$.

Statistical analysis of data considering both species together. To check if there is a correlation between the variables analyzed, a correlation test was applied along with the $t$ Student statistical test with $1 \%$ and $5 \%$ significance. The Variance test was also used to check the variance equality of the variables weight, depth and distance between the species. Considering an interval from -1.6 to 1.6 for the Stat $t$ test (standardized $t$ Student test), there is equality for the variables.

Thus, considering both species together, the correlation between distance and depth is -0.38 , which indicates a significant correlation due to sample size (976). When the $t$ Student test was applied, a value of -8.59 was obtained with $1 \%$ as well as $5 \%$, which means that the more distant from the center of the arena the larvae were, the less deep they buried.

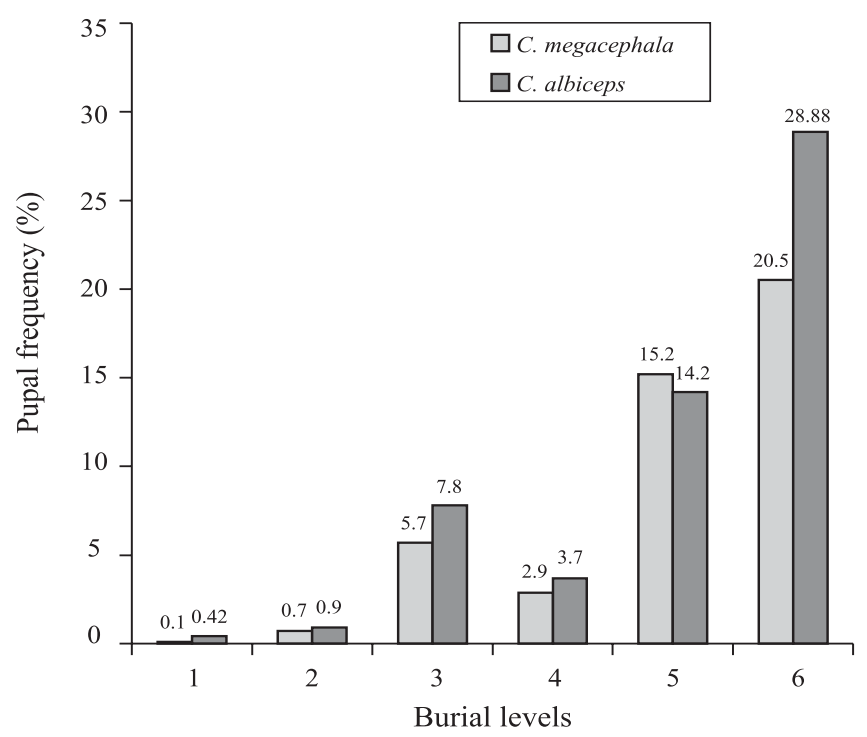

Fig. 3. Pupal frequency $(\mathrm{n}=976)$ of $C$. albiceps and C. megacephala at different burial levels. 


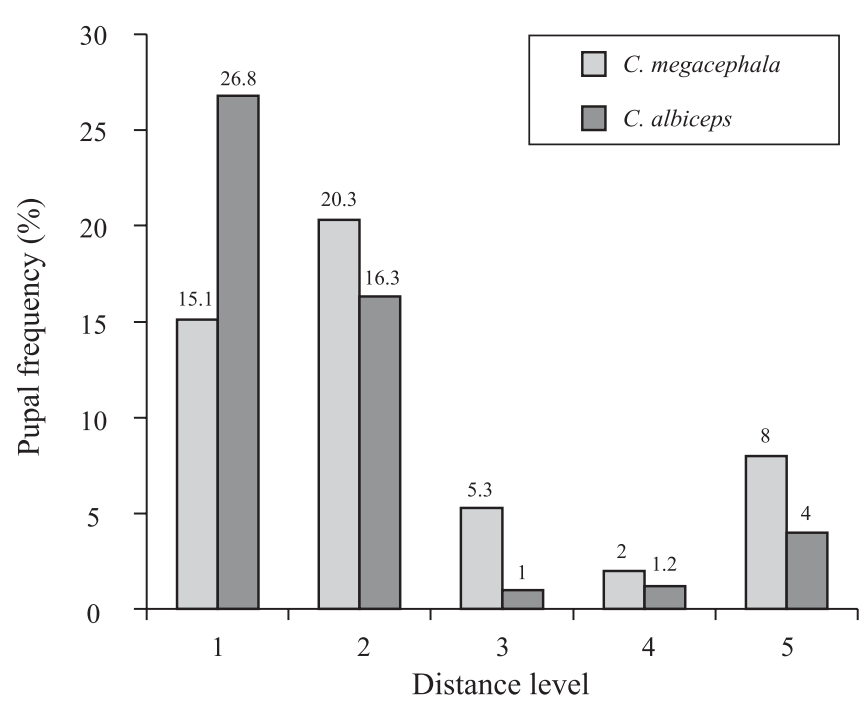

Fig. 4. Pupal frequency $(\mathrm{n}=976)$ of C. albiceps and C. megacephala per distance level, where 1 includes the interval from 0 to $20 \mathrm{~cm}, 2$ includes the interval from $21 \mathrm{~cm}$ to $40 \mathrm{~cm}, 3$ includes the interval from $41 \mathrm{~cm}$ to $60 \mathrm{~cm}, 4$ includes the interval from $61 \mathrm{~cm}$ to $80 \mathrm{~cm}$ and finally 5 includes the interval from $81 \mathrm{~cm}$ to $100 \mathrm{~cm}$ from the center of arena.

Considering depth and weight, a correlation of 0.4 was obtained, demonstrating that there is a strong and significant correlation between these variables. When the t Student test was applied, a value of 5.498 was obtained with $1 \%$ and $5 \%$, meaning that the heavier the larvae, the deeper they bury.

Finally, considering the variables of weight and distance, a significant correlation of -0.11 was obtained. The $t$ Student test yielded a value of -13.23 with both $1 \%$ and $5 \%$ demonstrating that the farther the larvae are from the center, the less they weigh.

Variance test checking the equality of the different variables. Considering the variable distance between both species, a Stat t value of -7.78 was obtained, indicating that the mean distances the two species traveled are not equal.

Regarding depth, C. albiceps larvae reached an average of $4.01 \mathrm{~cm}$ and C. megacephala reached $4.05 \mathrm{~cm}$, which corresponds to a Stat $t$ value of 0.65 , showing that the average depth reached by both species was equal.

Finally, considering weight, the mean values obtained were $41.34 \mathrm{mg}$ for C. albiceps and $46.57 \mathrm{mg}$ for C. megacephala, with a corresponding Stat $t$ value of 1.92 indicating that the weight averages of the two species are not close. This is different from the others works (Gomes \& Von Zuben 2003) where mean values of $42.89 \mathrm{mg}$ for $C$. albiceps and $42.41 \mathrm{mg}$ for C. megacephala were obtained, with a Stat $t$ value of 1.22 indicating close values in terms of weight.

\section{DISCUSSION}

This study demonstrated some general aspects on the dispersion process of larvae in a circular arena and confirmed former results using deeper arenas of smaller diameter. The lightest larvae tend to move longer distances, perhaps searching for new sources of food, and not for a site to pupate (Gomes et al. 2002).

The greatest concentration of pupae was found in distances greater than $15 \mathrm{~cm}$ (Figure 3) and 26 larvae reached the maximum distance from the center $(1 \mathrm{~m})$. Apparently, what limited larval movement the most in this study was burial depth, not distance from the center. The use of an arena with $2 \mathrm{~m}$ in diameter and $5 \mathrm{~cm}$ of depth allowed the larvae to travel longer distances than other recent studies where the arena had $50 \mathrm{~cm}$ in diameter and $20 \mathrm{~cm}$ depth (Gomes et al. 2003). Larval movement probably took place mainly to find a pupation site, even though the possibility that some pupae were searching for an additional source of food cannot be discarded (Gomes et al.2002).

With regard to the distribution of larvae per quadrant, quadrant 2 was preferred, while in other experiments where only one species was considered, an average of $31.17 \%$ preferred quadrant 1 and only $15.25 \%$ preferred quadrant 2 (Gomes \& Von Zuben 2002; Gomes et al. 2003). This might mean that larvae do not have any preference in distributing themselves in the quadrants, to be confirmed in future experiments.

Former studies had considered a trough $3 \mathrm{~m}$ long and 30 $\mathrm{cm}$ wide for the larval dispersion process. This trough allowed larval movements in only two directions (Godoy et al. 1995, 1996; Bassanezi et al. 1997). With the use of a circular arena, this study reflects better the conditions of the natural environment the larvae will face when they abandon their feeding substrate in search of a site to pupate (Ullyett 1950). A circular arena allows a radial dispersion from a central feeding substrate unlike the dispersion in only two directions allowed by a trough.

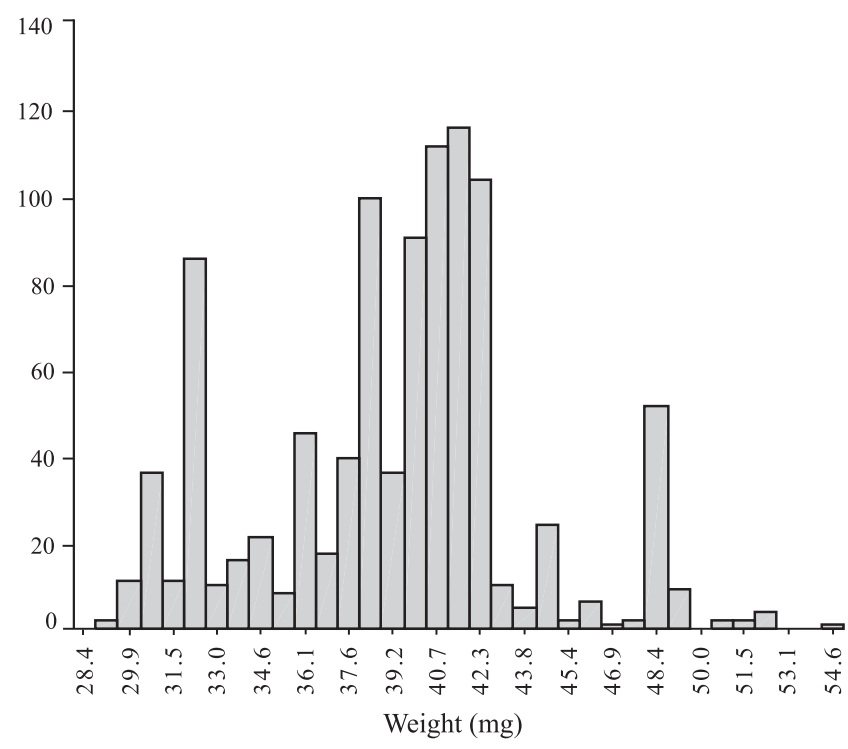

Fig. 5. Number of C. albiceps and C. megacephala pupae per weight class $($ Std. Dev $=4.69 ;$ Mean 39.2; $\mathrm{N}=976$ ). 
Table II. Distribution of C. albiceps and C. megacephala males (M) and females (F) according to each variable tested.

\begin{tabular}{lcccc}
\hline Species & & Gender & $\begin{array}{c}\text { Number of } \\
\text { larvae }\end{array}$ & Average \\
\hline \multirow{4}{*}{ C. albiceps } & Distance & $\mathrm{F}$ & 265 & 23.44 \\
& (cm) & $\mathrm{M}$ & 223 & 20.34 \\
& Total & 488 & 22.02 \\
& Depth & $\mathrm{F}$ & 265 & 4.00 \\
& Weight & $\mathrm{M}$ & 223 & 4.02 \\
& Total & 488 & 4.01 \\
& (mg) & $\mathrm{M}$ & 265 & 38.97 \\
& Total & 223 & 39.02 \\
& Distance & $\mathrm{F}$ & 224 & 39.00 \\
\hline \multirow{5}{*}{ (cm) } & $\mathrm{M}$ & 232 & 31.93 \\
& & Total & 456 & 31.83 \\
& Depth & $\mathrm{F}$ & 224 & 4.20 \\
& (cm) & $\mathrm{M}$ & 232 & 3.90 \\
& Total & 456 & 4.05 \\
& Weight & $\mathrm{F}$ & 224 & 39.57 \\
& (mg) & $\mathrm{M}$ & 232 & 39.55 \\
& & Total & 456 & 39.56 \\
\hline
\end{tabular}

Godoy et al. $(1995,1996)$ observed an oscillation in pupal frequency as a function of distance from the feeding substrate for C. megacephala (F.) as well as for C. putoria (Wied.). According to Boldrini et al. (1997), these oscillations would be a consequence of the creation of larval aggregations in certain sites of the pupation substrate. It could be possible that the dispersing larvae can somehow feel the density of other larvae already buried in a certain area of the substrate, and that would cause those larvae to move further in search of more distant pupation sites.

The post-feeding larval dispersion behavior and the consequent pattern of spatial distribution of pupae in pupation sites could have implications on greater or lesser larval susceptibility to predator or parasitoid attacks on natural environment populations (Peschke et al. 1987; Legner 1997). Chrysomya albiceps larvae prey on C. megacephala larvae during larval dispersion and that the latter probably disperse farther and deeper, precisely to escape predation (Goodbrod \& Goof 1990; Wells \& Greenberg 1992; Hanski 1997; Faria et al. 1999, 2001).

Another fact is that the larvae do not distribute themselves uniformly into the arena, which differs from former experiments (Gomes et al. 2003). Chrysomya albiceps larvae concentrated closer to the center of the arena and did not show, therefore, a uniform distribution (uniformity vector of 0.1 , not significant) as in study of Gomes \& Von Zuben 2003, while C. megacephala larvae present a uniform distribution (uniformity vector of 0.19 , significant) (Gomes et al. 2003).

It is interesting to note that these dispersion studies could have important implications for medico-criminal investigations as the presence of larvae and pupae in or around human corpses could help estimate the time interval between the person's death and the moment the body was found, called postmortem interval (PMI). This estimation is one of the most important aspects of legal medicine (Smith 1986), because it could be underestimated if the dispersing larvae are not taken into account (Von Zuben et al. 1998).

Acknowledgements. The authors would like to FAPESP by financial support (Process 03/00540-3) and to Iracema Monteiro da Silva collecting the data.

\section{REFERENCES}

Atkinson, W. D. \& B. Shorrocks. 1981. Competition on a divided and ephemeral resource: a simulation model. Journal of Animal Ecology 50: 461-471.

Backer, K. 1991. An analysis of factors which determine success in competition for food among larvae of Drosophila melanogaster. Archives of Neederland Zoology 14: 200-281.

Backer, K. 1969. Selection for rate of growth and its influence on competitive ability of larvae of Drosophila melanogaster. Netherland Journal of Zoology 19: 541-595.

Bassanezi, R. C.; M. B. F. Leite; W. A. C. Godoy; C. J. Von Zuben; F. J. Von Zuben \& S. F. Reis. 1997. Diffusion model applied to postfeeding larval dispersion in blowflies (Diptera: Calliphoridae). Memórias do Instituto Oswaldo Cruz 92: 281-286.

Boldrini J. L.; R. C. Bassanezi; A. C. Moretti; C. J. Von Zuben; W. A. C. Godoy; F. J. Von Zuben \& S. F. Reis. 1997. Non- local interactions and the dynamics of dispersal in immature insects. Journal of Theoretical Biology 185: 523-531.

de Jong, G. 1976. A model of competition for food. I. Frequencydependent viabilities. American Naturalist 110: 1013-1027.

Faria, L. D. B.; L. Orsi; L. A. Trinca \& W. A. C. Godoy. 1999. Larval predation by Chrysomya albiceps on Cochliomyia macellaria, Chrysomya megacephala and Chrysomya putoria. Entomologia Experimentalis et Applicata 90: 149-155.

Faria, L. D. B. \& W. A. C. Godoy. 2001. Prey choice by facultative predator larvae of Chrysomya albiceps (Diptera: Calliphoridae). Memórias do Instituto Oswaldo Cruz 96: 875-878.

Furlanetto, S. M. P.; M. L. C. Campos; C. M. Hársi; G. M. Buralli \& G. K. Ishihata. 1984. Microrganismos enteropatogênicos em moscas africanas pertencentes ao gênero Chrysomya (Diptera: Calliphoridae) no Brasil. Revista de Microbiologia 15: 170174.

Godoy, W. A. C.; H. G. Fowler; C. J. Von Zuben; L. Ziti \& O. B. Ribeiro. 1995. Larval dispersion in Chrysomya megacephala, C. putoria and Cochliomyia macellaria (Diptera: Calliphoridae). Journal of Applied Entomology 119: 263-266.

Godoy, W. A. C.; S. F. Reis. \& C. J. Von Zuben. 1996. Larval dispersal in Chrysomya megacephala, Chrysomya putoria and Cochliomyia macellaria (Diptera: Calliphoridae): Ecological implications of aggregation behavior. Journal of Applied Entomology 120: 423426.

Gomes, L.; C. J. Von Zuben. \& J. S. Govone. 2002. Comportamento da dispersão larval radial pós-alimentar em moscas-varejeiras do gênero Chrysomya (Diptera: Calliphoridae): busca por novas fontes de alimento. Entomologia y Vectores 9: 115-132.

Gomes, L. \& C. J. Von Zuben. 2003. Dispersão larval pós-alimentar em Chrysomya megacephala (F.) (Diptera: Calliphoridae): Profundidade, Distância e Peso de enterramento para pupariação. Bioscience Journal 18: 67-76.

Gomes, L. \& C. J. Von Zuben. 2003. Distribuição larval radial pósalimentar em Chrysomya albiceps (Wied.) (Diptera: Calliphoridae): profundidade, distância e peso de enterramento para pupação. Entomologia y Vectores 10: 211-222.

Greenberg, B. 1990. Behavior of postfeeding larvae of some Calliphoridae and a muscid (Diptera). Annals of Entomological Society of America 83: 1210-1214. 
Guimarães, J. H.; N. Papavero \& A. P. Prado. 1983. As miíases na região neotropical (identificação, biologia, bibliografia). Revista Brasileira de Zoologia 1: 239-416.

Hanski, I. 1987. Carrion fly community dynamics: patchiness, seasonality and coexistence. Ecological Entomology 12: 257266.

Hengeveld, R. 1989. Dynamics of biological invasions. New York, Chapman \& Hall.

Kocarek, P. 2001. Diurnal patterns of postfeeding larval dispersal in carrion blowflies (Diptera, Calliphoridae). European Jounal of Entomology 98: 117-119.

Legner, E. F. 1977. Temperature, humidity and depth of habitat influencing host destruction and fecundity of muscoid fly parasites. Entomophaga 22: 199-206.

Levot, G. W.; K. R. Brown \& E. Shipp. 1979. Larval growth of some calliphorid and sarcophagid Diptera. Bulletin of Entomological Research 69: 469-475.

Lima, M. L. P. S. \& E. Luz. 1991. Espécies exóticas de Chrysomya (Diptera, Calliphoridae) como veiculadoras de enterobactérias patogênicas em Curitiba, Paraná, Brasil. Acta Biológica do Paraná 20: $61-83$.

Lomnicki, A. 1988. Population ecology of individuals. Princeton: Princeton Press, 233 p.

Peschke, K.; D. Krapf \& D. Fuldner. 1987. Ecological separation, functional relationships, and limiting resources in a carrion insect community. Zoological Jb. System. 114: 241-265.

Reis, S. F.; G. Stangenhaus; W. A. C. Godoy; C. J. Von Zuben \& O. B.
Ribeiro. 1994. Variação em caracteres bionômicos em função de densidade larval em Chrysomya megacephala e Chrysomya putoria (Diptera: Calliphoridae). Revista Brasileira de Entomologia 38: 33-34.

Smith, K. G. V. (1986). A Manual of Forensic Entomology. Cornell University Press, Ithaca, 206 p.

Ullyett, G. C. 1950. Competition for food and allied phenomena in sheep-blowfly populations. 1950. Philosophical Transactions of The Royal Society of London B234: 77-174.

Von Zuben, C. J.; R. C. Bassanezi; S. F. Reis; W. A. C. Godoy \& F. J. V. Zuben. 1996. Theoretical approaches to forensic entomology: I. Mathematical model of postfeeding larval dispersal. Journal of Applied Entomology 120: 379-382.

Von Zuben, C. J. 1998. Comportamento de oviposturas individuais, percentagem de eclosão e peso larval mínimo para pupação em populações de Chrysomya megacephala (F.). Anais da Sociedade Entomológica do Brasil 4: 525-533.

Wells, J. D. \& B. Greenberg. 1992. Interaction between Chrysomya rufifacies and Cochliomyia macellaria (Diptera: Calliphoridae): the possible consequences of an invasion. Bulletin of Entomological Research 82: 133-137.

Wiens, J. A. (1976). Population responses to patchy enviroments. Annual Review of Ecological System 7. 81-120.

Zar, J. H. 1999. Biostatistical Analysis. Prentice Hall, New Jersey, $666 \mathrm{p}$.

Zumpt, F. 1965. Myiasis in man and animals in the Old World. London, Butterworths, 267 p. 